\title{
The post-depositional changes of the onshore 2004 tsunami deposits on the Andaman Sea coast of Thailand
}

\author{
Witold Szczuciński
}

Received: 31 August 2009/Accepted: 15 May 2011/Published online: 31 August 2011

(C) The Author(s) 2011. This article is published with open access at Springerlink.com

\begin{abstract}
The Indian Ocean tsunami flooded the coastal zone of the Andaman Sea and left tsunami deposits with a thickness of a few millimetres to tens of centimetres over a roughly one-kilometre-wide tsunami inundation zone. The preservation potential and the post-depositional changes of the onshore tsunami deposits in the coastal plain setting, under conditions of a tropical climate with high seasonal rainfall, were assessed by reinvestigating trenches located along 13 shore-perpendicular transects; the trenches were documented shortly after the tsunami and after 1, 2, 3 and 4 years. The tsunami deposits were found preserved after 4 years at only half of the studied sites. In about $30 \%$ of the sites, the tsunami deposits were not preserved due to human activity; in a further $20 \%$ of the sites, the thin tsunami deposits were eroded or not recognised due to new soil formation. The most significant changes took place during the first rainy season when the relief of the tsunami deposits was levelled; moderate sediment redeposition took place, and fine surface sediments were washed away, which frequently left a residual layer of coarse sand and gravel. The fast recovery of new plant cover stabilised the tsunami deposits and protected them against further remobilisation during the subsequent years. After five rainy seasons, tsunami deposits with a thickness of at least a few centimetres were relatively well preserved; however, their internal structures were often significantly blurred by roots and animal bioturbation. Moreover, soil formation within the deposits caused alterations, and in the case of thin layers, it was not possible to recognise them anymore. Tsunami boulders were only slightly weathered but not moved. Among the various factors influencing the preservation potential, the thickness of the original tsunami deposits is the most important. A comparison between the first post-tsunami survey and the preserved record suggests that tsunamis with a run-up smaller than three metres are not likely to be preserved; for larger tsunamis, only about $50 \%$ of their inundation area is likely to be presented by the preserved extent of the tsunami deposits. Any modelling of paleotsunamis from their deposits must take into account post-depositional changes.
\end{abstract}

W. Szczuciński (\)

Institute of Geology, Adam Mickiewicz University, Maków Polnych 16, 61-606 Poznań, Poland e-mail: witek@amu.edu.pl 
Keywords Tsunami deposits · Preservation potential · Post-depositional changes · Indian Ocean tsunami · Coastal zone · Thailand

\section{Introduction}

Tsunamis are long sea waves that are usually generated by earthquakes, explosive volcanic activity, submarine slides or asteroid impact. They present a serious hazard to coastal communities as proved by the tsunami on 26 December 2004, which was the most destructive in recorded history. The occurrence and extent of the Indian Ocean tsunami were unprecedented in most of the impacted regions, which contributed to the large number of tsunami victims. Thus, the first step to improve the preparedness of coastal communities is to provide a tsunami hazard assessment that is essentially based on the studies of past events and helps to determine both potential inundation areas and recurrence periods. However, historical records are normally too short to register more than one tsunami. This is why studies on the sedimentary record of past tsunamis (paleotsunami) are so important (e.g. Minoura and Nakaya 1991; Clague et al. 2000; Nanayama et al. 2003; Pinegina et al. 2003; Goff et al. 2010).

Explicit identification of paleotsunami deposits is often difficult because of several reasons. Tsunami deposits are represented by various sediment types, which range from mud to boulders. Furthermore, they are similar to other deposits, for instance storm deposits (e.g. Morton et al. 2007; Switzer and Jones 2008). There is no simple diagnostic set of criteria to identify tsunami deposits easily (Dawson and Shi 2000; Goff et al. 2001; Scheffers and Kelletat 2003; Morton et al. 2007; Bourgeois 2009). However, when the deposits are identified, their detailed studies are useful to assess the water velocity, the depth of past tsunami inundations and source locations and to understand how the tsunami affected the coastal geomorphology (e.g. Jaffe and Gelfenbuam 2007; Smith et al. 2007).

Modern tsunami deposits often display more complex internal stratigraphy than their ancient counterparts. For instance, the first discovered paleotsunami deposits in Thailand (Jankaew et al. 2008; Fujino et al. 2009) are massive and depleted in microfossils compared to the 2004 tsunami deposits from the same area, which reveal many sedimentary structures and are rich in both diatoms and foraminifera (Choowong et al. 2008a; Sawai et al. 2009). Therefore, understanding how post-depositional processes modify tsunami deposits and attempting to quantify the nature and the rate of these changes are essential not only to interpret the flow conditions of paleotsunamis but also to identify paleotsunami deposits at all.

The last decade was a period of significant progress in tsunami sedimentology; the importance of the preservation potential problem, in particular for the case of onshore (subaerial) deposits, was recognised (e.g. Minoura et al. 1997; Dawson and Shi 2000; Rhodes et al. 2006; Weiss and Bahlburg 2006; Keating et al. 2008). However, only few studies were dedicated to post-depositional changes and the preservation potential of tsunami deposits. A major difficulty is due to the need for documentation of tsunami deposits shortly after a tsunami and then to make time-series documentation in the following months and years. The depositional effects of the 2004 Indian Ocean tsunami were well documented and intensively studied shortly after the tsunami in many regions with different geological and climatic conditions (e.g. Kench et al. 2006; Bahlburg and Weiss 2007; Choowong et al. 2007, 2008a, b; Kelletat et al. 2007; Paris et al. 2007, 2009; Srinivasalu et al. 2007; Fujino et al. 2008). The post-tsunami recovery of coastal zones was 
generally found to be relatively fast - on the order of a few months to a few years (Choowong et al. 2009; Grzelak et al. 2009; Kendall et al. 2009; Liew et al. 2009; Wong 2009). Several studies focused on the recovery of tsunami-affected soils (e.g. Hulugalle et al. 2009; McLeod et al. 2010). However, relatively little attention was paid to postdepositional alteration and the preservation of the onshore tsunami deposits, while only a few systematic studies were conducted.

The study by Nichol and Kench (2008) was dedicated to the preservation of carbonate sand sheets that were deposited by the 2004 tsunami on several islands in the Maledives. They found that within 2 years, significant reworking and bioturbation of the tsunami deposited layer occurred. They concluded that the relatively narrow belt of sandy tsunami deposits covering mid-ocean atolls has a low to moderate preservation potential. Several accounts of the preservation of the 2004 tsunami deposits are available from coastal zones in Thailand. Goto et al. (2008, in review) reinvestigated several transects in Bang Sak and Khao Lak (Fig. 1) at 3 months, 9 months (after the rainy season) and 4-5 years after the tsunami. They noted that the deposits were covered with vegetation and disturbed by roots; they reported that the thickness of the deposits was not altered or reduced to $\sim 70 \%$ of the original thickness. Jankaew et al. (2008) noted that in the investigated sites on Phra Thong Island (north from Kho Khao IslandFig. 1), in swales a new layer of organic matter that was as thick as $5 \mathrm{~cm}$ covered the 2004 tsunami layer. In contrast, it lacked any cover on the ridges and mixing by burrowing organisms was observed. Szczuciński et al. (2006) briefly reported observations that were made shortly after the tsunami and 1 year later (after the rainy season) along several transects (Fig. 1). They noted that, on the coastal plain, the tsunami deposits were generally well preserved apart from areas that were either modified by extensive man-made changes or where the thickness of the original tsunami deposited layer was on the order of $1 \mathrm{~cm}$ or less. Szczuciński et al. (2007) presented the results of tsunami deposit observations, grain size analyses and chemical analyses of major ions ('salts'), acid-leached ('bioavailable') heavy metals and metalloids after the first rainy season from 15 sites (around Patong Bay, Bang Mor and Nham Kem-see Fig. 1), which were investigated in the same way shortly after the tsunami (Szczuciński et al. 2005). They found that the visible thickness of the tsunami deposits layer decreased in places where it was thin $(1-2 \mathrm{~cm})$, and at the surface, coarse grains became enriched. Moreover, they recorded a dramatic decrease in the salt content and a sustained relatively high content of heavy metals and arsenic in the deposits. Kozak et al. (2008) performed arsenic speciation analyses on samples that were collected from the same 15 sites shortly after the tsunami and at 1 and 2 years later. They found that shortly after the tsunami, inorganic arsenic was present in a highly toxic form, As(III), and in a less toxic form, As(V). After 2 years, only $\mathrm{As}(\mathrm{V})$ was observed, which is probably due to ongoing oxidation and associated geochemical changes.

The present work aims to extend the previous observations made after 1 year (Szczuciński et al. 2006) and supplement them with observations in the following years. The tsunami deposits from trenches that were located in 13 shore-perpendicular transects along the Andaman Sea coast of Thailand (Fig. 1) were documented shortly after the tsunami and at 1, 2, 3 and 4 years after the tsunami (Fig. 2). The objective of the study is to assess the preservation potential and the post-depositional changes of the onshore tsunami deposits in a coastal plain setting under tropical conditions with high seasonal rainfall. 


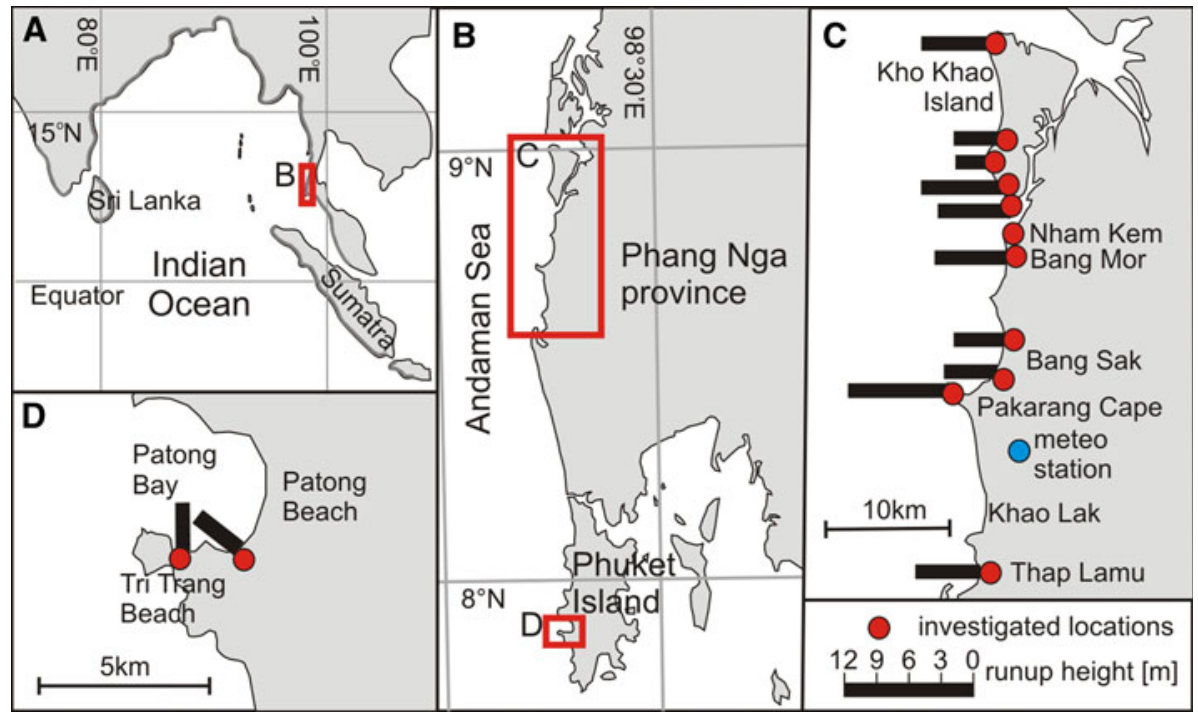

Fig. 1 Study area. a Location within the Indian Ocean; coasts that were impacted by the 2004 tsunami are marked by a bold line. b Coastal zone of Thailand that was subjected to the major 2004 tsunami impact. c Investigated sites (transects), average tsunami run-up heights and location of the meteorological station ('meteo station', source of data for Fig. 2) in Phang Nga province. d Investigated sites (transects) and average tsunami run-up heights on Phuket Island. Site-averaged tsunami run-up data are from Szczuciński et al. (2006) and for Thap Lamu and Pakarang Cape from Choowong et al. (2008a)

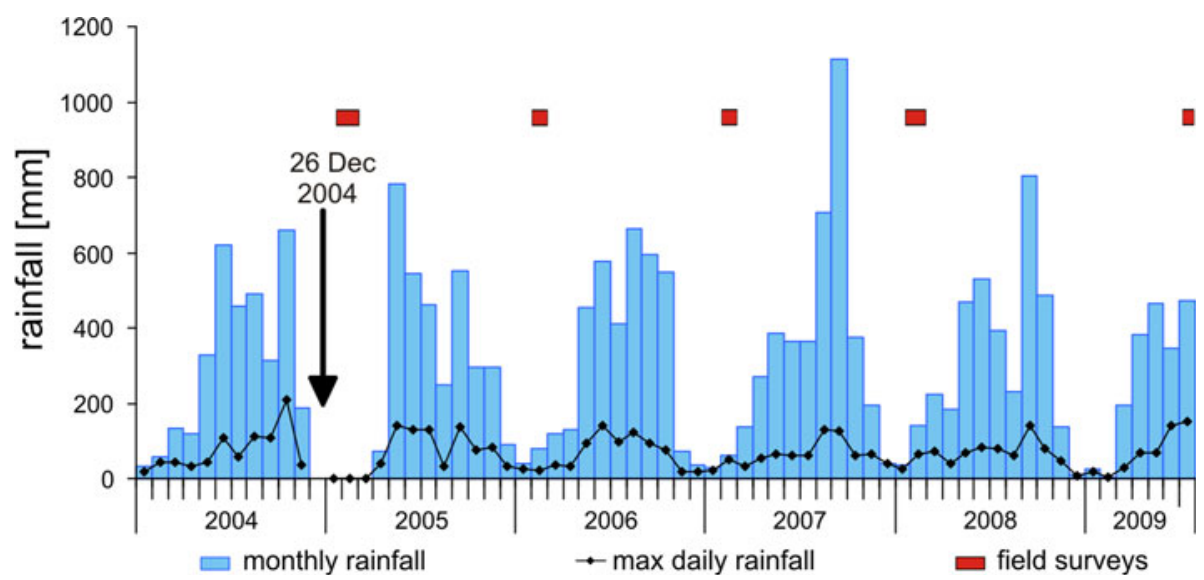

Fig. 2 Monthly sums of the rainfall and maximum daily rainfalls as recorded at the Phang Nga province meteorological station (Fig. 1) and the periods of the conducted field surveys. Rainfall data are from January 2004 to July 2009, apart from December 2004 when the station was damaged. Data kindly provided by the Phang Nga meteorological office

\section{Setting}

The study was conducted in the coastal zone of western Thailand (Phang Nga province and on Phuket Island), which faces the Andaman Sea (Fig. 1). The investigated sites represent 
either rocky shorelines with small pocket beaches and narrow coastal plains (Tri Trang, Patong and Thap Lamu) or long sandy beaches in front of an up to $3 \mathrm{~km}$-wide coastal plains (Bang Sak, Bang Mor, Nham Kem and Kho Khao Island). The coastal plain has an undulating relief due to old beach ridges and intervening swales as well as placer deposits mining. The region is characterised by a warm climate with precipitation of about $3,000 \mathrm{~mm}$ per year that is focused during the rainy season (May to September; Fig. 2), when strong SW winds prevail. The maximum daily rainfall can reach above $200 \mathrm{~mm}$ (Fig. 2). During the rainy season, the depressions (swales) are usually submerged due to high groundwater levels.

The 26 December 2004 tsunami inundated the coastal plain up to a few hundred metres to more than one kilometre inland. The tsunami run-up height at the maximum inundation limit varied from $<3 \mathrm{~m}$ in parts of Kho Khao Island's coast, which is protected by an offshore reef, to almost $10 \mathrm{~m}$ at Nham Kem and on the Pakarang Cape (Fig. 1). The tsunami wave's height was even higher, reaching over $15 \mathrm{~m}$ in Nham Kem (Tsuji et al. 2006) and at Pakarang Cape (Siripong 2006).

The wave caused the death of several thousand people, heavy damages, coastal erosion and environmental changes (e.g. Bell et al. 2005; Szczuciński et al. 2005, 2006; Ghobarah et al. 2006; Siripong 2006; Rossetto et al. 2007). Most of the inundated area was blanketed with a layer of tsunami deposits having a thickness of a few to several tens of centimetres and being mainly composed of silty sand and sand (e.g. Szczuciński et al. 2006; Hori et al. 2007; Choowong et al. 2008a; Goto et al. 2008) with occasional boulders (e.g. Goto et al. 2007; Kelletat et al. 2007).

The studied sites were investigated shortly after the tsunami event, and the sedimentological properties of the tsunami deposits were reported (Szczuciński et al. 2006, in review). Moreover, sediments from 15 sites from Patong, Bang Mor and Nham Kem were studied with regard to their geochemistry including contents of salt, acid-leachable metals and exchangeable metalloids (Szczuciński et al. 2005, 2007), mercury fractionation (Boszke et al. 2006), arsenic speciation (Kozak et al. 2008), acid-leachable trace elements (Kozak et al. 2009) and labile aluminium content (Zioła-Frankowska et al. 2009). The sedimentological properties of the tsunami deposits at Bang Sak were also documented by Goto et al. (2008) and Matsumoto et al. (2008); at Bang Mor and Nham Kem by Hori et al. (2007), Umitsu et al. (2007), Kokociński et al. (2009) and Naruse et al. (2010); and at Kho Khao Island by Jagodziński et al. (2009). The boulder deposits near Thap Lamu and at Pakarang Cape were described by Yawsangratt et al. (2009) and Goto et al. (2007), respectively.

\section{Materials and methods}

This study is based on observations obtained during five field surveys. The first one took place in January-February 2005, which was $<2$ months after the tsunami. Since no rainfall or strong winds were reported between the tsunami and the fieldwork, it is highly likely that the tsunami deposits were preserved in an unaltered form. The subsequent surveys took place after the rainy seasons in February 2006, 2007 and 2008, and during the rainy season in July 2009 (Fig. 2). In February 2005, over 100 trenches were documented in 13 transects (Szczuciński et al. in review). In the following years, 59 sites were reinvestigated every year, and a further 40 sites were revisited at least once.

Although it was attempted to reinvestigate places as close to the original position as possible by using maps, orientation landmarks and GPS coordinates, it must be noted that 
the distance was usually at least several metres. There are several reasons for this. First, it was avoided to dig a trench in the same place as before because the tsunami deposits layer was already disturbed during the previous digging and covering with ground. Furthermore, several places that were relatively easy to access shortly after the tsunami were not reachable in the following years because of reconstruction works, private property and very dense vegetation.

At each site, the following features were observed: surface relief, vegetation cover, stage of new soil development, human activity, thickness of tsunami deposits, effects of bioturbation, sedimentary structures, contact of the tsunami deposits with the underlying and covering sediments, visual estimate of grain size and sorting of the tsunami deposits, preservation of shells, buried plants, and so on. Moreover, the type and thickness of the pre-tsunami soil was documented-as a possible scenario for further development of posttsunami soils. For the boulder deposits, particular attention was paid to rock surface changes that occur due to subaerial weathering.

\section{Results}

\subsection{Vegetation cover}

Two months after the tsunami, no vegetation recovery was observed because the original soil was buried by a blanket of tsunami deposits having a high salt content, saline ground water and standing surface waters, and the lack of rain until April 2005 (Szczuciński et al. 2005, 2006). One year later, the vegetation had already recovered, and in successive years, a continuous increase in the density and height of the plants was observed (Fig. 3). A good example of fast recovery is the Casuarina trees. After $4 \frac{1}{2}$ years, the young trees were found to be over $10 \mathrm{~m}$ high and had a circumference of over $65 \mathrm{~cm}$. The vegetation had a protective role for the tsunami deposits against heavy rains and erosion; however, the root systems cause mixing of the sediments and alteration of sedimentary structures (Fig. 4). The development of plant cover varied spatially and was dependent on various factors, including topography, pre-tsunami soil type, thickness of tsunami deposits, etc. For instance, in regions with thick, medium-to-coarse sand sediments (pre-tsunami and tsunami), the vegetation remained poor even after a few years. In many places, the recovery was affected by human activities, for instance by controlled fires (Fig. 4).

Shortly after the tsunami, bent plants (grass, etc.) were commonly found within the deposits and served as a good indicator of the flow direction. In the following years, the withered plants were rarely found in the tsunami deposits, apart from the silty, stiff tsunami
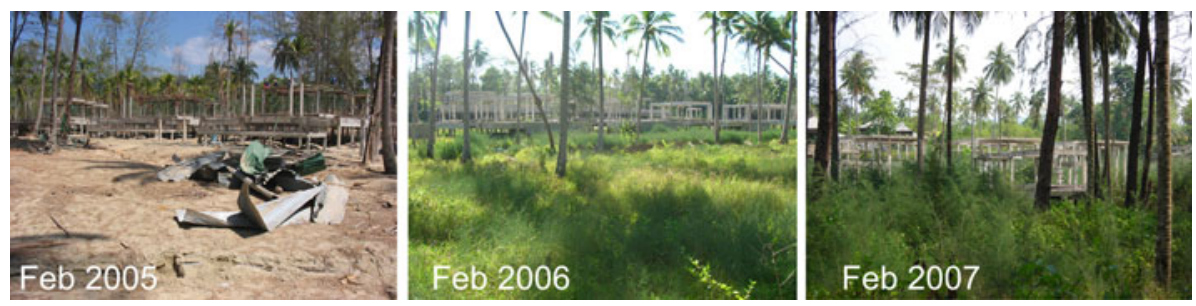

Fig. 3 Changes in the vegetation cover after the tsunami in Bang Sak. In February 2005, the area was covered with $20-40 \mathrm{~cm}$ of tsunami-laid sand. In the following years, the plants increased in size and density. In the year 2008, the vegetation was so high and dense that it was not possible to take the comparable picture 

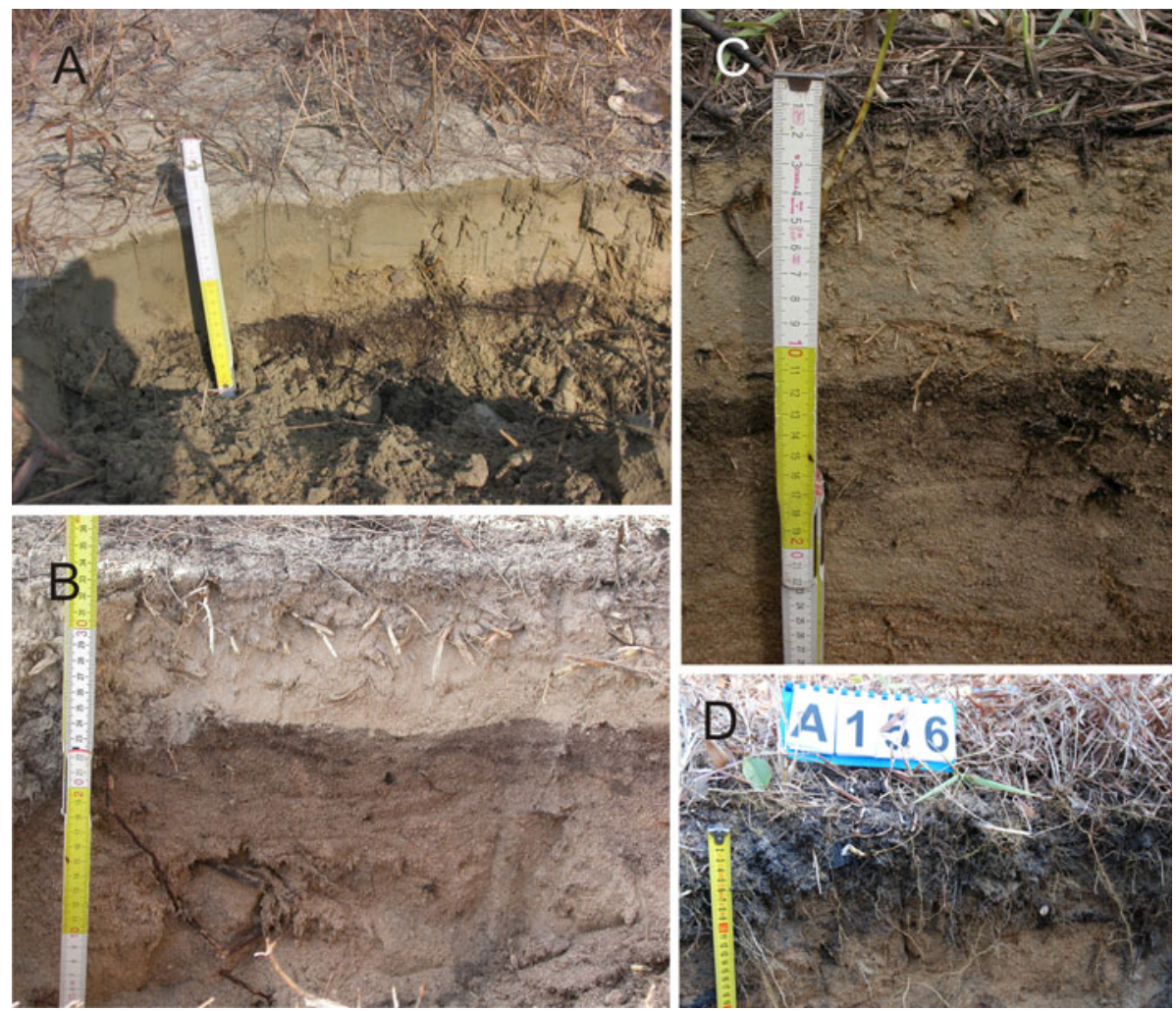

Fig. 4 Examples of the preservation of tsunami deposits and the development of root systems. a An 11-cmthick layer of tsunami deposits with fining upward grain size with buried pre-tsunami plants in February 2005 in the central part of the Kho Khao Island coastline. b A 10-cm-thick tsunami deposits layer with a dense root system in February 2007 at the same site as in a. c A 10-cm-thick tsunami deposits layer with roots throughout the layer, February 2007, Bang Mor. d Site with unrecognisable tsunami deposits due to fire and mixing from roots, February 2008, northern Kho Khao Island

deposits where they were still preserved. Most likely, in the easily mixed and bioturbated sandy sediments, the plant remnants had decomposed and were consumed.

\subsection{Tsunami deposits relief}

In February 2005, the tsunami deposits layer still revealed relief features that were related to water flow: sedimentary bedforms (ripples), ridges adjacent to obstacles, as well as generated by vortexes rows of circular hollows (Szczuciński et al. in review). Already 1 year after the tsunami, they were mostly unrecognisable. The areas with ripples were covered with plants, and often the surface of the tsunami deposits were deformed by grazing cattle, etc. The circular hollows (up to $20 \mathrm{~cm}$ deep) were covered with redeposited sediments from the surrounding area. Only the biggest (almost $10 \mathrm{~m}$ long) ridge, which was deposited on the lee side of a tree in southern Kho Khao, was partially preserved. However, it is doubtful to determine its origin without the first post-tsunami survey observations. 


\subsection{Extent of the tsunami deposits}

During the first survey, the tsunami deposits were found almost within the entire inundation area apart from a belt nearby the flooding limit and a zone next to the shoreline within about $50 \mathrm{~m}$, where erosion or sediment bypassing dominated. The spatial extent of recognisable tsunami deposits was largely diminished throughout the study period, which was primarily due to human activity such as earth works and agriculture. For instance, around Patong Bay in July 2009, tsunami deposits were still preserved in only one site from the 33 investigated in 2005. The main reason was land reclamation for new investments. Moreover, in general, tsunami deposits with a thickness of 1-2 cm were already unrecognisable after 1 year; thus, the landward limit of recognisable tsunami deposits was largely diminished in general to less than $550 \mathrm{~m}$ from the shoreline. Altogether, at about half of the investigated sites including those affected by human activity, the tsunami deposits were not recognised during reinvestigation.

\subsection{Thickness of the tsunami deposits}

The tsunami deposit's thickness ranged from millimetres to more than half a metre (Fig. 5). The small-scale variations in thickness at a distance of tens of centimetres were on the order of several centimetres caused by small changes in the microrelief of the pretsunami ground or sedimentary bed forms of tsunami deposits. Thus, it is not possible to give precise information about changes in the tsunami deposits thickness since the reinvestigated sites were at least a few metres away in the following years. However, where tsunami deposits have been recognised over the years, their thickness changed very little (Figs 4, 6, 7). After the first year, in a few places, redeposition was observed to cause filling of the above-mentioned hollows and a thin layer of new sediment eroded elsewhere

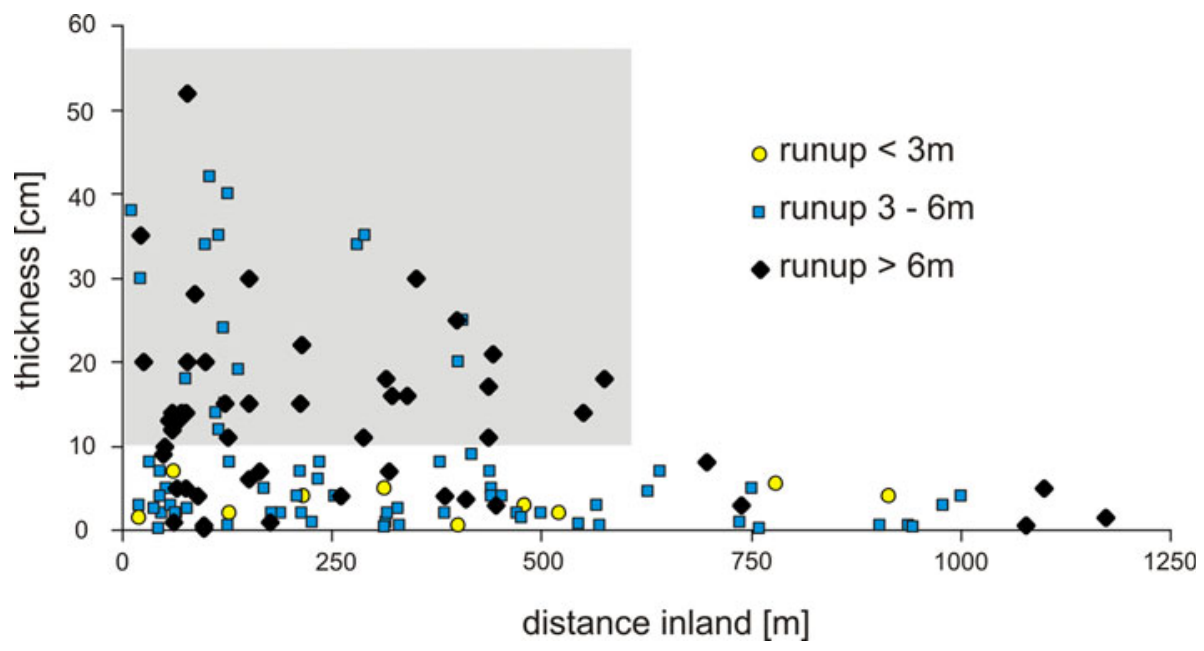

Fig. 5 Changes to the onshore tsunami deposit's thickness with the distance from the shoreline. Documented for parts of the coastline with various tsunami run-up heights (data from Szczuciński et al. in review). The grey field indicates sites with a relatively high preservation potential. See text for further discussion 
was found on top of the tsunami sediments in some swales. During the following years, these new sediments were mixed with tsunami deposits due to soil development.

\subsection{Lower contact of the tsunami deposits}

The tsunami deposit's basal contact was usually sharp while formed above organic-rich soil, which made the identification fairly simple. In such cases, the contact was still sharp for the following seasons (Figs. 4, 6, 7, 8). However, when tsunami deposits overlay sandy sediments bounded by very thin soil or an erosional surface, the lower contact is commonly very difficult to recognise after only one rainy season. The grain size spectrum of the pretsunami soil and the tsunami deposits is, in many cases, very similar. Frequently, the recognition of the lower contact of the tsunami deposits was possible only due to experience and documentation of the original situation shortly after the tsunami.

\subsection{Tsunami deposit's grain size}

The major macroscopic change was the fast removal of the thin layer of very fine sediments initially representing the top of the tsunami deposits (Figs 6 and 8). In case that the deposits originally consisted of poorly sorted medium to coarse sand and in particular in places with sparse vegetation, a type of residual layer of coarse material is left over. Consequently, the typical fining upward of tsunami deposits has changed after few years to a coarsening upward.

\subsection{Structures of the tsunami deposits}

The investigated tsunami deposits revealed a variety of primary sedimentary structures. The deposits consisted of one, two or more layers. The layers were mostly massive, with a fining upward trend, or laminated. Moreover, cross-laminations, mud clasts, mud films, floating boulders, heavy minerals enrichments and internal erosional structures were observed (Szczuciński et al. in review). Almost all the near-surface structures of the tsunami deposits were removed with time. Tsunami deposits thinner than $10 \mathrm{~cm}$ usually
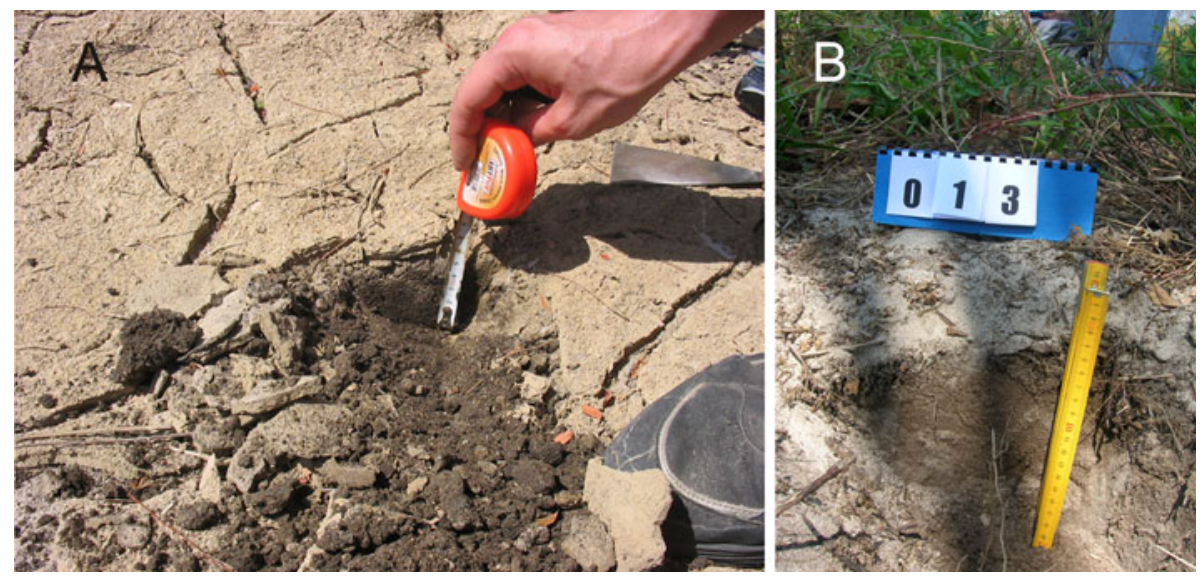

Fig. 6 Thin 1-2-cm tsunami deposits at nearby Tri Trang beach in 2005 (a) and 2006 (b). The upper crust was composed of silty sand that was missing after 1 year 

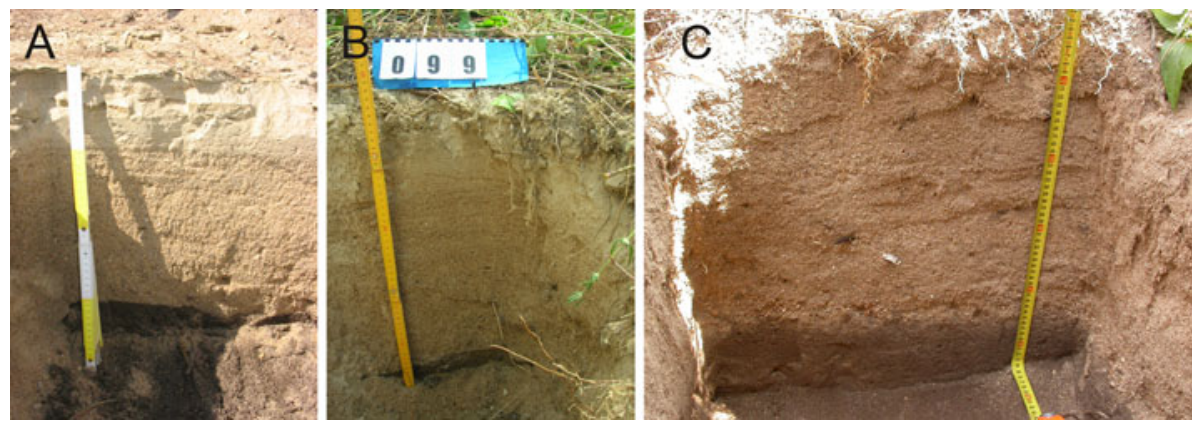

Fig. 7 Thick layer of laminated tsunami deposits covering dark pre-tsunami soil on southern Kho Khao Island. State in a 2005, b 2006 and c 2007
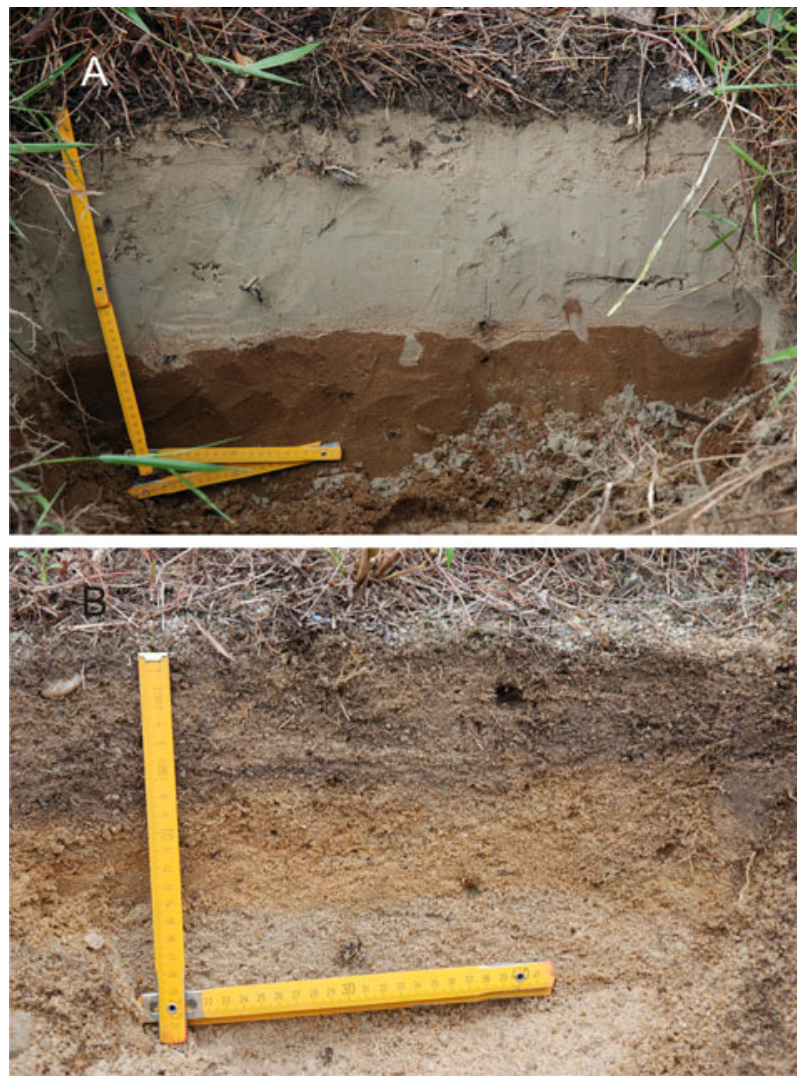

Fig. 8 Examples of the preservation of tsunami deposits in July 2009. a A 30-cm-thick silty sand intercalated with two thin sand layers, with a well-preserved variable lower contact and $1-4 \mathrm{~cm}$ of new soil at the top, Bang Sak. b About 5-cm-thick sandy tsunami deposits with lower contacts masked by new soil formations. At the surface, a thin residual lamina of coarse sand and gravel, Thap Lamu

changed to a massive appearance after 1 or 2 years; then only remnants of the primary structures, for instance fining upward, are left. This is mainly due to bioturbation by growing roots and burrowing animals like crabs and rodents (Fig. 9). Tsunami deposits 


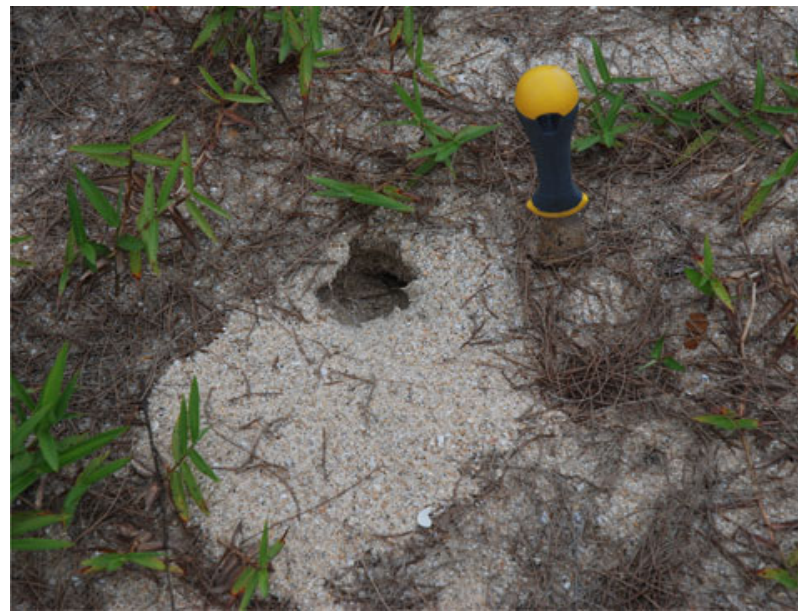

Fig. 9 Example of a crab burrowing that causes, in some places, a complete overturning of tsunami deposits and mixing with pre-tsunami sediments, Nham Kem

thicker than $10 \mathrm{~cm}$ or those composed of stiff silty sand contain the primary sedimentary structures, which apart from the upper few centimetres, are still well preserved after five rainy seasons (Figs 7,8 ).

\subsection{Development of new soils}

As soon as the seawater had withdrawn, the tsunami deposits started to serve as substrate for vegetation initiating soil formation. At the beginning, probably the high salt content restricted recolonisation by plants; after 2 months, new soil was hardly recognised. However, after 1 year at most of the investigated sites, soil development was observed. The most evident features are dense root systems, an increase in organic matter content leading to darker sediment colour, mixing of the sediments disturbing primary sedimentary structures, and in some cases, formation of a new humus layer (Figs. 4, 7 and 8). The new soil developed largely by sediment reworking and mixing with organic matter from new plant cover deposited on the top of the tsunami deposits.

After 4 years, the new soil was of variable thickness, depending on the type of substrate and vegetation cover. It was still poorly developed on thick sandy tsunami deposits that were left on sandy pre-tsunami soil (Fig. 7), which caused significant changes in the tsunami deposit's properties only in a surface layer with a 1-2 cm thickness. Evident new soil reaching up to $5 \mathrm{~cm}$ thickness was developed on the tsunami deposits if composed of silty sand and silt (Fig. 8a). However, the deposits below the soil were usually well preserved. In the case of sandy tsunami deposits of intermediate to small thicknesses, the soil usually is up to $10 \mathrm{~cm}$ thick. Then, the tsunami deposits are often blurred and mixed with pre-tsunami soil, sediments and new soil components (Figs. 4, 8). Consequently, tsunami deposits thinner than the newly developed soil became unrecognisable. In places where human activity altered the soil through cultivation, earth works comprising over $30 \%$ of the studied sites, the tsunami deposits were usually unrecognisable and the upper organic-rich soil unit was less clearly visible. 
During the field survey, the characteristics and thickness of the upper, organic-rich, pretsunami soil were also observed. Since the dominant coastal plain sediments are very similar to the tsunami deposits in terms of grain size, one may expect the new soil to reach the thickness of the pre-tsunami soil. On average, the thickness of the well-developed organic-rich part of the pre-tsunami soil, which entirely masked the characteristics of the former sediments, was about $10 \mathrm{~cm}$.

\subsection{Tsunami boulders}

The boulders that were transported by the tsunami were monitored at two sites: Pakarang Cape and near Thap Lamu (Fig. 1). At the first site, significant coastal erosion was observed and numerous boulders composed of detached coral reef blocks were left in the intertidal zone (Goto et al. 2007). During the following years, the sandy-gravelly ridge was naturally rebuilt but the boulders were not moved away. Some of the boulders were partly buried in sandy gravel sediments. Many of the boulders became darker on the surface due to subaerial weathering and incrustation. At the second site, 18 granite boulders partly covered with oyster shells were transported from the coastline up to $140 \mathrm{~m}$ inland (Yawsangratt et al. 2009). The only observed changes were partial dissolution of the carbonate shells that covered the boulders and darkening of the fresh broken rock surfaces due to ongoing weathering.

\section{Discussion}

\subsection{Evolution of the onshore tsunami deposits}

The observations are the base to propose a simple generalised model of the post-depositional evolution of the onshore tsunami deposits in a tropical climate with high seasonal rainfall (Fig. 10). Two main stages are distinguished in areas that are not significantly affected by human activity. The first stage lasts from the tsunami until the development of plant cover during the first rainy season. The second stage spans the following years.

Due to flooding by the tsunami waves, the inundated part of the coastal plain was covered with a nearly continuous layer of tsunami deposits. The deposits varied in thickness from a few millimetres to more than 0.5 metres, had a complex internal structure and were often capped with the fine sediments. The relief of sedimentary bedforms was preserved well in the first stage (Szczuciński et al. 2006, in review; Choowong et al. 2007, 2008a, b; Hori et al. 2007; Goto et al. 2008). The deposits were wet and contained high amounts of salt (Szczuciński et al. 2005). In the following months until April 2005, no rain occurred (Fig. 2). Thus, the vegetation development was hindered by drought and high salt content in the tsunami deposits. In that period, the redeposition of surface sediment by wind was limited due to the presence of a surface crust that was composed of the fine, cohesive sediment and salt, and very weak winds during that season.

The major changes in the tsunami deposits took place during the first rainy season, when almost 3,000 mm of rainfall occurred with a daily maximum rainfall of $141.4 \mathrm{~mm}$ (Figs 2, 10). The rains caused washing of the tsunami deposits and removal of easily soluble salts (Szczuciński et al. 2007). Precipitation also caused moderate sediment mobilisation and redeposition; tsunami deposits thinner than $1 \mathrm{~cm}$ were occasionally washed away, the depositional relief was flattened and deposits at the slopes were partially eroded. The finest particles that form the cap of the tsunami deposits were partly removed, and the surface of 


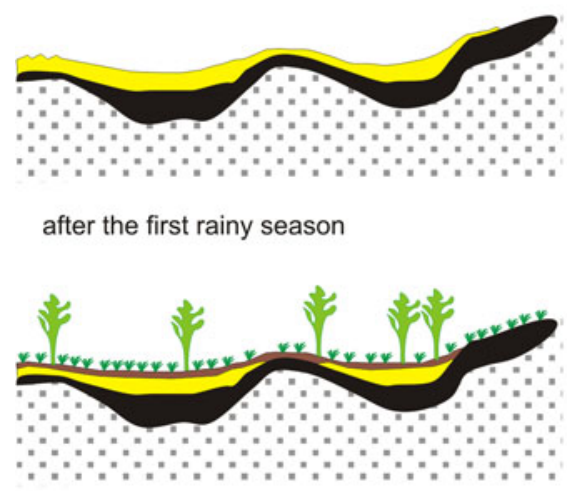

- heavy rains

- rapid removal of salts

- moderate sediment

redeposition

- leveling of sediment

surface

- washing out of the surface

fine sediments

- bioturbation by roots and animals

- formation of initial soils

after following rainy seasons

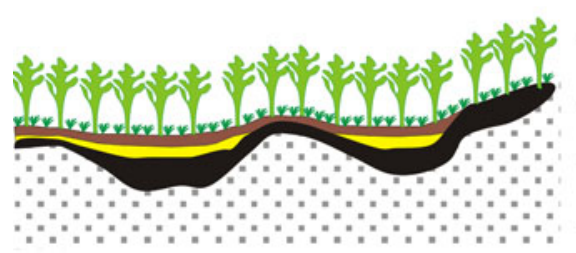

- stabilization of ground surface by dense plant cover

- bioturbation by roots and animals

- incorporating of tsunami deposits into new soil - oxidation of metals and metalloids

-dissolution of carbonate shells

Fig. 10 Schematic presentation of the post-depositional history of the 2004 tsunami deposits on a coastal plain in Thailand. Visual presentation is supplemented with the associated main processes that are listed to the right. The thickness of particular layers is not to scale

the tsunami deposits became composed of coarser grains forming a kind of residual deposit. The removal of salts and availability of freshwater allowed the plants to colonise the coastal plain. The vegetation cover provided a shelter for the tsunami deposits against heavy rains and erosion. However, vegetation accelerated the formation of new soil and the destruction of tsunami deposits structure by plant roots and animals.

During the following years, although the rainfall was even higher than in 2005, the tsunami deposits were not subjected to major changes. A dense plant cover established and stabilised the ground surface, thereby limiting sediment remobilisation. Once again, growing roots and animals induced intensive disturbance of the tsunami deposits, which caused a partial destruction of the internal sedimentary structure. The rapidly developing new surface layer was mostly composed of the tsunami deposits and plant debris. The soil forming processes alter the tsunami deposits significantly since then. Thus, thin deposits became unrecognisable. In subsequent years, it is expected that the soil formation will continue to reach the pre-tsunami state having an upper organic matter-rich soil horizon being on average up to $10 \mathrm{~cm}$ thick.

Exceptions from this scenario were also observed. Moreover, post-depositional changes to the onshore tsunami deposits may be quite different for other climatic conditions. For instance, they may be subjected primarily to wind action and redeposition (e.g. Goff et al. 2008) 
or protected from external factors for most of the year by snow cover and frost (e.g. MacInnes et al. 2009).

\subsection{Preservation potential of the tsunami deposits}

There are no universal criteria to grade the preservation potential. Here is used a simply grading into: low preservation (generally no deposits left or very difficult to recognize), moderate preservation (deposits exists but are altered in several ways), and good preservation (preserved in terms of thickness but also structures etc.). Preservation of the sedimentary record from the 2004 tsunami event after five rainy seasons is generally moderateto-good for layers $>2 \mathrm{~cm}$ in thickness, except in areas with human activity such as cleaning works and new investments. Nonetheless, it is expected that the tsunami deposits that are thinner than $10 \mathrm{~cm}$ may be completely altered by soil formation and mixing processes. Therefore, the tsunami deposits will be unrecognisable as event deposit because of its similarity in grain size with the underlying coastal plain sediments and the blurring of the lower, originally sharp surface. In the case of deposits that are thicker than $10 \mathrm{~cm}$, even when some diagnostic features such as sedimentary structures are altered, the presence of buried soil below and the occurrence of microfossils and mineralogical and geochemical composition may help to identify them (e.g. Jankaew et al. 2008; Jagodziński et al. 2009; Sawai et al. 2009; Chagué-Goff 2010; Chagué-Goff et al. 2011). However, Yawsangratt et al. (2011) observed that carbonate foraminifera tests were subjected to significant dissolution already 4.5 years after tsunami.

The most important control of the preservation potential appears to be the initial thickness of the tsunami deposited layer, which is a function of the tsunami wave's run-up and velocity as well as the volume of sediment available for transport. In the studied case, there is a relationship between the tsunami run-up's height and the thickness of the tsunami deposits (Fig. 5). Where the tsunami run-up was smaller than $3 \mathrm{~m}$, the deposits thickness was smaller than $3 \mathrm{~m}$, the deposits thickness was less than $10 \mathrm{~cm}$. If the above presented deduction that the future development of soils extinguishes tsunami deposits thinner than $10 \mathrm{~cm}$ from the sedimentary record is correct, then the deposits of tsunamis with a run-up smaller than $3 \mathrm{~m}$ have little chance of being preserved. Tsunami deposits formed by bigger waves exhibit a thickness of less than $10 \mathrm{~cm}$ at a distance from the shoreline larger than about $550 \mathrm{~m}$ approximately half of the inundation distance (Fig. 5). Thus, although the deposits potentially should record the tsunami event, the information concerning the tsunami inundation distance may be missing.

The studied boulder deposits had been almost untouched since the 2004 tsunami; however, it is not straightforward to use boulders to detect paleotsunami events because of difficulties in interpreting their storm or tsunami origin (e.g. Mastronuzzi et al. 2006; Goto et al. 2010) and problems with dating of an event (e.g. Yawsangratt et al. 2009). The observations of fresh granite boulders showed that attached oyster shells, which would potentially be a very good dating material, were subjected to fast dissolution.

The tsunami recurrence time for the Andaman coast of Thailand was evaluated by Løvholt et al. (2006), based on an analysis of the plate tectonic situation, earthquake history and numerical modelling. They concluded that it would take at least 300-400 years to accumulate the energy that was released during the December 2004 earthquake. They also estimated that tsunamis with a run-up height of $1.5-2 \mathrm{~m}$ and a recurrence of 50-100 years are possible. If the preservation potential of the sedimentary record from tsunamis with a run-up smaller than $3 \mathrm{~m}$ is correctly estimated, then a record of smaller tsunamis has a very low preservation potential. The first discovered records of 
paleotsunamis from the Andaman coast of Thailand showed that the last paleotsunami was 550-700 years ago (Jankaew et al. 2008); it was probably of a similar magnitude as the 2004 tsunami. The lack of a sedimentary record for a tsunami in between may be due to the low preservation potential of smaller event records.

Lowe and de Lange (2000) suggested, based on a study from New Zealand, that a tsunami needs to have a wave height of at least $5 \mathrm{~m}$ in order to leave any long-term, recognisable sedimentary signature. Their conclusion was later supported by an analysis of former tsunami records by Goff et al. (2010). Since the wave height is usually higher than the run-up height, this statement can be treated as being generally in agreement with the present results - a run-up of $3 \mathrm{~m}$ is a minimum value for a sedimentary record of a tsunami to be preserved.

Ancient tsunami deposits may be used not only for the identification of previous events but also for interpreting their flow conditions. However, the observed post-depositional changes of the primary sedimentary features reduce the possibility of using fossil tsunami deposits to estimate the number of waves or to model the paleotsunami's onshore flow depth or speed (e.g. Huntington et al. 2007; Jaffe and Gelfenbuam 2007; Smith et al. 2007). The estimations and models are based on the sedimentary structures, tsunami deposit's thickness and grain size; in other words, they are features that are susceptible to post-depositional changes.

\subsection{Preservation of event deposits in a coastal plain environment}

Tsunami deposits belong to a group of event deposits. The latter occurs in almost all types of sedimentary basins and may be left by various processes: floods, storms, earthquakes, slumps, turbidity currents, etc. (e.g. Einsele et al. 1996). Their preservation potential was already investigated in various environments and for a variety of event deposits: flood layers on continental shelves (e.g. Wheatcroft and Drake 2003; Bentley et al. 2006), volcanoclastic deposits in the deep sea (Wetzel 2009), onshore paleocyclone deposits (Collins et al. 1999; Mertz et al. 2003) and others. The most important factors that influence the preservation of event layers were found to be the sediment accumulation rate, mixing rate and event layer thickness (Wheatcroft 1990). Although models that were developed in the above-mentioned studies could be applied to assess the preservation of tsunami deposits in marine, intertidal, lagoon or lacustrine environments, they have limited application for the coastal plain environment that was discussed in the present paper. The major difference in the case of tsunami deposits on land is due to the general domination of sediment erosion over sediment accumulation. The preservation of event deposits (tsunami deposits, storm deposits, etc.) in the coastal plain setting could be defined by three factors: the deposit's thickness, the mixing depth and erosion. The deposits would be preserved if the thickness were bigger than the sum of the erosion and mixing depth. In practice, however, this model appears to be too simple. The basic problem is the spatial variability in the thickness, erosion and mixing. Moreover, in some places (e.g. swales), accumulation may take place. Additionally, the mixing depth and rate in soils cannot be easily defined (Wilkinson et al. 2009). The root systems may reach several metres below the ground, and due to processes of soil formation, the mixing of the event deposits with adjacent sediments is variable. It is likely that the post-depositional processes that act on the event layers in the coastal plain setting are geographically so diverse (various climate, topography, vegetation, etc.) that it is not possible to formulate a universal rule to quantify their preservation potential. It is also important to take into account not only the preservation of a layer but also the post-depositional changes within the layer, which may cause the layer to remain visible but not allow its origin to be explained. 


\section{Conclusions}

The 5 years of observations of post-depositional changes to the 2004 tsunami deposits that were left on a coastal plain in a tropical climate with high seasonal rainfall proved that the deposits are generally preserved, although the coastal plain is not a favourite setting for the preservation of event deposits. The most significant changes were due to human activity, which may alter not only the modern deposits but also the paleotsunami deposits that were left in the coastal zone. The natural changes to the 2004 tsunami deposits took place in two stages. The first stage was within 1 year after the tsunami, when moderate redeposition, erosion, levelling of the sediment surface, removal of salts, removal of fine particles from the sediment surface and moderate sediment mixing took place. It was mostly related to high rainfalls falling on the uncovered sediment's surface. The second stage was related primarily to fast stabilisation of the ground by dense plant cover and the ongoing development of new soil. The post-depositional changes seem to be strongly related to the environment, setting and climate.

Analysis of the post-depositional changes, new soil formation and pre-tsunami soil characteristics implies that tsunami deposits that are thinner than $10 \mathrm{~cm}$ have little preservation potential. Consequently, the sedimentary record of tsunamis with a run-up smaller than $3 \mathrm{~m}$ is not likely to be preserved at all, while for larger tsunamis, only about $50 \%$ of their inundation area is likely to be preserved by the extent of tsunami deposits. Modelling of paleotsunami parameters that are based on paleorecords must take into account the postdepositional changes (particularly related to the soil's formation) since the model's input parameters (thickness, grain size) are subjected to modifications.

Acknowledgments The study was financially supported by the Polish Ministry of Science and Higher Education through research grant No. N N523 376833 and by Adam Mickiewicz University in Poznań, Poland. The logistical support was kindly provided by the Department of Mineral Resources in Bangkok, Thailand. The author thanks N. Chaimanee, S. Chatpresert, R. Jagodziński, M. Kokociński, L. Kozak, S. Lorenc, P. Niedzielski, G. Rachlewicz, D. Saisuttichai, A. Szczucińska, T. Tepsuwan, S. Yawsangratt and other colleagues from the Department of Mineral Resources in Bangkok for invaluable help during field work and fruitful discussions. The paper benefited from constructive comments and corrections on the earlier version of the manuscript by A. Wetzel.

Open Access This article is distributed under the terms of the Creative Commons Attribution Noncommercial License which permits any noncommercial use, distribution, and reproduction in any medium, provided the original author(s) and source are credited.

\section{References}

Bahlburg H, Weiss R (2007) Sedimentology of the December 26, 2004, Sumatra tsunami deposits in eastern India (Tamil Nadu) and Kenya. Int J Earth Sci 96:1195-1209

Bell R, Cowan H, Dalziell E, Evans N, O’Leary M, Rush B, Yule L (2005) Survey of impacts on the Andaman Coast, Southern Thailand following the great Sumatra-Andaman earthquake and tsunami of December 26, 2004. Bull N Z Soc Earthquake Eng 38:123-148

Bentley SJ, Sheremet A, Jaeger JM (2006) Event sedimentation, bioturbation, and preserved sedimentary fabric: Field and model comparisons in three contrasting marine settings. Cont Shelf Res 26: 2108-2124

Boszke L, Kowalski A, Szczuciński W, Rachlewicz G, Lorenc S, Siepak J (2006) Assessment of mercury mobility and bioavailability by fractionation method in sediments from coastal zone inundated by the 26 December 2004 tsunami in Thailand. Environ Geol 51:527-536 
Bourgeois J (2009) Geologic effects and records of tsunamis. In: Bernard EN, Robinson AR (eds) Tsunamis. The Sea, ideas and observations on progress in the study of the seas, vol.15. pp, Harvard University Press, pp 55-91

Chagué-Goff C (2010) Chemical signatures of paleootsunamis: A forgotten proxy? Mar Geol 271:67-71

Chagué-Goff C, Schneider J-L, Goff JR, Dominey-Howes D, Strotz L (2011) Expanding the proxy toolkit to help identify past events: lessons from the 2004 Indian Ocean tsunami and the 2009 South Pacific tsunami. Earth Sci Rev 107:107-122

Choowong M, Murakoshi N, Hisada K, Charusiri P, Daorerk V, Charoentitirat T, Chutakositkanon V, Jankaew K, Kanjanapayont P (2007) Erosion and deposition by the 2004 Indian Ocean tsunami in Phuket and Phang-nga Provinces, Thailand. J Coast Res 23:1270-1276

Choowong M, Murakoshi N, Hisada K, Charoentitirat T, Charusiri P, Phantuwongraj S, Wongkok P, Choowong A, Subsayjun R, Chutakositkanon V, Jankaew K, Kanjanapayont P (2008a) Flow conditions of the 2004 Indian Ocean tsunami in Thailand, inferred from capping bedforms and sedimentary structures. Terra Nova 20:141-149

Choowong M, Murakoshi N, Hisada K, Charusiri P, Charoentitirat T, Chutakositkanon V, Jankaew K, Kanjanapayont P, Phantuwongraj S (2008b) 2004 Indian Ocean tsunami inflow and outflow at Phuket, Thailand. Mar Geol 248:179-192

Choowong M, Phantuwongraj S, Charoentitirat T, Chutakositkanon V, Yumuang S, Charusiri P (2009) Beach recovery after 2004 Indian Ocean tsunami from Phang-nga, Thailand. Geomorphology 104: $134-142$

Clague JJ, Bobrowsky PT, Hutchinson I (2000) A review of geological records of large tsunamis at Vancouver Island, British Columbia, and implications for hazard. Quat Sci Rev 19:849-863

Collins ES, Scott DB, Gayes PT (1999) Hurricane records on the South Carolina coast: Can they be detected in the sediment record? Quat Int 56:15-26

Dawson A, Shi S (2000) Tsunami deposits. Pure Appl Geophys 157:875-897

Einsele G, Chough SK, Shiki T (1996) Depositional events and their records-an introduction. Sed Geol 104:1-9

Fujino S, Naruse H, Suphawajruksakul A, Jarupongsakul T, Murayama M, Ichihara T (2008) Thickness and grain-size distribution of Indian Ocean tsunami deposits at Khao Lak and Phra Thong Island, Southwestern Thailand. In: Shiki T, Tsuji Y, Yamazaki T, Minoura K (eds) Tsunamiites-features and implications. pp, Elsevier B.V., pp 123-132

Fujino S, Naruse H, Matsumoto D, Jarupongsakul T, Sphawajruksakul A, Sakakura N (2009) Stratigraphic evidence for pre-2004 tsunamis in southwestern Thailand. Mar Geol 262:25-28

Ghobarah A, Saatcioglu M, Nistor I (2006) The impact of the 26 December 2004 earthquake and tsunami on structures and infrastructure. Eng Structures 28:312-326

Goff J, Chagué-Goff C, Nichol S (2001) Palaeotsunami deposits: A New Zealand perspective. Sed Geol $143: 1-6$

Goff J, McFadgen B, Wells A, Hicks M (2008) Seismic signals in coastal dune systems. Earth Sci Rev 89:73-77

Goff J, Nichol S, Kennedy D (2010) Development of a tsunami database for New Zealand. Nat Hazards 54:193-208

Goto K, Chavanich SA, Imamura F, Kunthasap P, Matsui T, Minoura K, Sugawara D, Yanagisawa H (2007) Distribution, origin and transport process of boulders deposited by the 2004 Indian Ocean tsunami at Pakarang Cape, Thailand. Sed Geol 202:821-837

Goto K, Imamura F, Keerthi N, Kunthasap P, Matsui T, Minoura K, Ruangrassamee A, Sugawara D, Supharatid S (2008) Distribution and significance of the 2004 Indian Ocean tsunami deposits: initial results from Thailand and Sri Lanka. In: Shiki T, Tsuji Y, Yamazaki T, Minoura K (eds) Tsunamiitesfeatures and implications. pp, Elsevier B.V., pp 105-122

Goto K, Miyagi K, Kawamata H, Imamura F (2010) Discrimination of boulders deposited by tsunamis and storm waves at Ishigaki Island, Japan. Mar Geol 269:34-45

Goto K, Takahashi J, Fujino S (in review) Variations in the 2004 Indian Ocean tsunami deposits thickness and their preservation potential, southwestern Thailand. Earth Planets Space

Grzelak K, Kotwicki L, Szczuciński W (2009) Monitoring of sandy beach meiofaunal assemblages and sediments after the 2004 tsunami in Thailand. Pol J Environ Stud 18:43-51

Hori K, Kuzumoto R, Hirouchi D, Umitsu M, Janjirawuttikul N, Patanakanog B (2007) Horizontal and vertical variation of 2004 Indian tsunami deposits: an example of two transects along the western coast of Thailand. Mar Geol 239:163-172

Hulugalle NR, Jaya R, Luther GC, Ferizal M, Daud S, Irhas Yatiman, Yufniati ZA, Feriyanti F, Tamrin HanB (2009) Physical properties of tsunami-affected soils in Aceh, Indonesia: 21/2 years after the tsunami. Catena 77:224-231 
Huntington K, Bourgeois J, Gelfenbaum G, Lynett P, Jaffe B, Yeh H, Weiss R (2007) Sandy signs of a tsunami's onshore depth and speed. EOS Trans AGU 88:577-578

Jaffe BE, Gelfenbuam G (2007) A simple model for calculating tsunami flow speed from tsunami deposits. Sed Geol 200:347-361

Jagodziński R, Sternal B, Szczuciński W, Lorenc S (2009) Heavy minerals in 2004 tsunami deposits on Kho Khao Island, Thailand. Pol J Environ Stud 18:103-110

Jankaew K, Atwater BF, Sawai Y, Choowong M, Charoentitirat T, Martin ME, Prendergast A (2008) Medieval forewarning of the 2004 Indian Ocean tsunami in Thailand. Nature 455:1228-1231

Keating BH, Wanink M, Helsey CE (2008) Introduction to a tsunami-deposits database. In: Shiki T, Tsuji Y, Yamazaki T, Minoura K (eds) Tsunamiites-features and implications. pp, Elsevier B.V., pp 359-381

Kelletat D, Scheffers SR, Scheffers A (2007) Field signatures of the SE-Asian mega-tsunami along the west coast of Thailand compared to Holocene paleo-tsunami from the Atlantic region. Pure Appl Geophys 164:413-431

Kench PS, McLean RF, Brander R, Nichol SL, Smithers S, Ford MR, Parnell K, Aslam M (2006) Geological effects of tsunami on mid-ocean atoll islands: the Maledives before and after the Sumatran tsunami. Geology 34:177-180

Kendall MA, Aryuthaka C, Chimonides J, Daungnamon D, Hills J, Jittanoon C, Komwachirapitak P, Kongkaew V, Mittermeyr A, Monthun Y, Nimsantijaroen S, Paterson GLJ, Foster-Smith R, FosterSmith J, Thongsin N (2009) Post-tsunami recovery of shallow water biota and habitats on Thailand's Andaman coast. Pol J Environ Stud 18:69-75

Kokociński M, Szczuciński W, Zgrundo A, Ibragimow A (2009) Diatom assemblages in 26 December 2004 tsunami deposits from coastal zone of Thailand as provenance indicators. Pol J Environ Stud 18:93-101

Kozak L, Niedzielski P, Szczuciński W (2008) The methodology and results of determination of inorganic arsenic species in mobile fractions of tsunami deposits by hyphenated technique of HPLC-HG-AAS. Int J Environ Anal Chem 88:989-1003

Kozak L, Machát J, Niedzielski P (2009) Content of 27 selected elements in the potentially mobile fraction of tsunami sediments. Pol J Environ Stud 18:131-136

Liew SC, Gupta A, Wong PP, Kwoh LK (2009) Recovery from a large tsunami mapped over time: The Aceh coast, Sumatra. Geomorphology 114:520-529

Løvholt F, Bungum H, Harbitz CB, Glimsdal S, Lindholm CD, Pedersen G (2006) Earthquake related tsunami hazard along the western coast of Thailand. Nat Hazards Earth System Sci 6:979-997

Lowe DJ, de Lange WP (2000) Volcano-meteorological tsunamis, the c. AD 200 Taupo eruption (New Zealand) and the possibility of a global tsunami. Holocene 10:401-407

MacInnes BT, Pinegina TK, Bourgeois J, Razhigaeva NG, Kaistrenko VM, Kravchunovskaya EA (2009) Field survey and geological effects of the 15 November 2006 Kuril tsunami in the middle Kuril Islands. Pure Appl Geophys 166:9-36

Mastronuzzi G, Pignatelli C, Sansò P (2006) Boulder fields: A valuable morphological indicator of palaeotsunami in the Mediterranean sea. Z Geomorph NF Suppl Bd 146:173-194

Matsumoto D, Naruse H, Fujino S, Surphawajruksakul A, Jarupongsakul T, Sakakura N, Murayama M (2008) Truncated flame structures within a deposit of the Indian Ocean tsunami: evidence of synsedimentary deformation. Sedimentology 55:1559-1570

McLeod MK, Slavich PG, Irhas Y, Moore N, Rachman A, Ali N, Iskandar T, Hunt C, Caniago C (2010) Soil salinity in Aceh after the December 2004 Indian Ocean tsunami. Agric Water Manage 97:605-613

Mertz LM, Hart M, Jaeger J (2003) Preservation potential of paleocyclone deposits in Gulf of Mexico coastal sediments. GCAGS/GCSSEPM Trans 53:537-547

Minoura K, Nakaya S (1991) Traces of tsunami preserved in inter-tidal lacustrine and marsh deposits: some examples from northeast Japan. J Geol 99:265-287

Minoura K, Imamura F, Takahashi T, Shuto N (1997) Sequence of sedimentation processes caused by the 1992 Flores tsunami: evidence from Babi Island. Geology 25:523-526

Morton RA, Gelfenbaum G, Jaffe BE (2007) Physical criteria for distinguishing sandy tsunami and storm deposits using modern examples. Sed Geol 200:184-207

Nanayama F, Satake K, Furukawa R, Shimokawa K, Atwater BF, Shigeno K, Yamaki S (2003) Unusually large earthquakes inferred from tsunami deposits along the Kuril trench. Nature 424:660-663

Naruse H, Fujino S, Suphawajruksakul A, Jarupongsakul T (2010) Features and formation processes of multiple deposition layers from the 2004 Indian Ocean tsunami at Ban Nam Kem, southern Thailand. Island Arc 19:399-411

Nichol SL, Kench PS (2008) Sedimentology and preservation potential of carbonate sand sheets deposited by the December 2004 Indian Ocean tsunami: South Baa Atoll, Maledives. Sedimentology 55: 1173-1187 
Paris R, Lavigne F, Wassmer P, Sartohadi J (2007) Coastal sedimentation associated with the December 26, 2004 tsunami in Lhok Nga, west Banda Aceh (Sumatra, Indonesia). Mar Geol 238:93-106

Paris R, Wassmer P, Sartohadi J, Lavigne F, Barthomeuf B, Desgages E, Grancher D, Baumert P, Vautier F, Brunstein D, Gomez C (2009) Tsunamis as geomorphic crises: Lessons from the December 26, 2004 tsunami in Lhok Nga, West Banda Aceh (Sumatra, Indonesia). Geomorphology 104:59-72

Pinegina TK, Bourgeois J, Bazanova LI, Melekestsev IV, Braitseva OA (2003) A millenial-scale record of Holocene tsunamis on the Kronotskiy Bay coast, Kamchatka, Russia. Quat Res 59:36-47

Rhodes B, Tuttle M, Horton B, Doner L, Kelsey H, Nelson A, Cisternas M (2006) Paleotsunami research. Eos 87:205, 209

Rossetto T, Peiris N, Pomonis A, Wilkinsin SM, Del Re D, Koo R, Gallocher S (2007) The Indian Ocean tsunami of December 26, 2004: Observations in Sri Lanka and Thailand. Nat Hazards 42:105-124

Sawai Y, Jankaew K, Martin ME, Prendergast A, Choowong M, Charoentitirat T (2009) Diatom assemblages in tsunami deposits associated with the 2004 Indian Ocean tsunami at Phra Thong Island, Thailand. Mar Micropaleontol 73:70-79

Scheffers A, Kelletat D (2003) Sedimentologic and geomorphologic tsunami imprints worldwide-a review. Earth Sci Rev 63:83-92

Siripong A (2006) Andaman seacoast of Thailand field survey after the December 2004 Indian Ocean tsunami. Earthquake Spectra 22:187-202

Smith DE, Foster IDL, Long D, Shi S (2007) Reconstructing the pattern and depth of flow onshore in a paleotsunami from associated deposits. Sed Geol 200:362-371

Srinivasalu S, Thangadurai N, Switzer AD, Ram Mohan V, Ayyamperumal T (2007) Erosion and sedimentation in Kalpakkam (N Tamil Nadu, India) from the 26th December 2004 tsunami. Mar Geol 240:65-75

Switzer AD, Jones BG (2008) Large-scale washover sedimentation in a freshwater lagoon from the southeast Australian coast: sea-level change, tsunami or exceptionally large storm? Holocene 18:787-803

Szczuciński W, Niedzielski P, Rachlewicz G, Sobczyński T, Zioła A, Kowalski A, Lorenc S, Siepak J (2005) Contamination of tsunami sediments in a coastal zone inundated by the 26 December 2004 tsunami in Thailand. Environ Geol 49:321-331

Szczuciński W, Chaimanee N, Niedzielski P, Rachlewicz G, Saisuttichai D, Tepsuwan T, Lorenc S, Siepak J (2006) Environmental and geological impacts of the 26 December 2004 tsunami in coastal zone of Thailand-overview of some short and long-term effects. Pol J Environ Stud 15:793-810

Szczuciński W, Niedzielski P, Kozak L, Frankowski M, Zioła A, Lorenc S (2007) Effects of rainy season on mobilization of contaminants from tsunami deposits left in a coastal zone of Thailand by the 26 December 2004 tsunami. Environ Geol 53:253-264

Szczuciński W, Rachlewicz G, Chaimanee N, Saisuttichai D, Tepsuwan T, Lorenc S (in review) 26 December 2004 tsunami deposits left in areas of various tsunami runup in coastal zone of Thailand. Earth Planets Space

Tsuji Y, Namegaya Y, Matsumoto H, Iwasaki SI, Kanbua W, Sriwichai M, Meesuk V (2006) The 2004 Indian tsunami in Thailand: Surveyed runup heights and tide gauge records. Earth Planets Space 58:223-232

Umitsu M, Tanavud C, Patanakanog B (2007) Effects of landforms on tsunami flow in the plains of Banda Aceh, Indonesia, and Nam Khem, Thailand. Mar Geol 242:141-153

Weiss R, Bahlburg H (2006) A note on the preservation of offshore tsunami deposits. J Sed Res $76: 1267-1273$

Wetzel A (2009) The preservation potential of ash layers in the deep-sea: the example of the 1991-Pinatubo ash in the South China Sea. Sedimentology 56:1992-2009

Wheatcroft RA (1990) Preservation potential of sedimentary event layers. Geology 18:843-845

Wheatcroft RA, Drake DE (2003) Post-depositional alteration and preservation of sedimentary event layers on continental margins, I. The role of episodic sedimentation. Mar Geol 199:123-137

Wilkinson MT, Richards PJ, Humphreys GS (2009) Breaking ground: pedological, geological, and ecological implications of soil bioturbation. Earth Sci Rev 97:254-269

Wong PP (2009) Impacts and recovery from a large tsunami: coasts of Aceh. Pol J Environ Stud 18:5-16

Yawsangratt S, Szczuciński W, Chaimanee N, Jagodziński R, Lorenc S, Chatprasert S, Saisuttichai D, Tepsuwan T (2009) Depositional effects of 2004 tsunami and hypothetical paleotsunami near Thap Lamu Navy Base in Phang Nga Province, Thailand. Pol J Environ Stud 18:17-23

Yawsangratt S, Szczuciński W, Chaimanee N, Chatprasert S, Majewski W, Lorenc S (2011) Evidence of probable paleotsunami deposits on Kho Khao Island, Phang Nga Province, Thailand. Nat Hazards. doi: 10.1007/s11069-011-9729-4

Zioła-Frankowska A, Frankowski M, Szczuciński W, Siepak J (2009) Analysis of labile aluminium form in grain size fractions of tsunami deposits in Thailand. Pol J Environ Stud 18:77-85 